\title{
OVATKO SOSIALSAATIO JA KASVATUS SAMOJA KÄSITTEITÄ?
}

\section{Pauli Siljander (toim.) 1997. Kasvatus ja sosiali- saatio. Gaudeamus}

Giljanderin (1997) toimittaman kirjan Kasvatus ja sosialisaatio arviointi on vaikea tehtävä. Teos koostuu kahdeksasta teoreettisesta artikkelista. K ir jassa käydään läpi sosialisaation ja kasvatuksen välinen yhteys, pedagoginen toiminta, pedagoginen tietoisuus, minä-teoria, semiotiikka kasvatuksen tutkimuksen osa-alueena ja psykoanalyyttinen sekä filosofinen näkökulma kasvatukseen ja sosialisaatio on. Perusteema rakentuu käsitteiden kasvatus (pedagoginen teoria) ja sosialisaatio (sosialisaatioteoria) väliseen erotteluun. Kirjoittajien Pauli Siljander, Jouni Peltonen, A ri Kivelä, Asko Karjalainen \& Pauli Siljander, Ari Sutinen, H enry V iheriävaara, E sa Pikkarainen, Timo Latomaa ja Toivo Salonen aihealueet kiinnittyvät kasvatusfilosofiaan, kasvatustieteeseen, semiotiikkaan ja kielitieteeseen sekä kasvatuspsykologiaan (psykoanalyysiin). Y hteinen teema niille on, väljästi tulkittuna, tulkinnallinen (ymmärtävä) näkökulma.

$\mathrm{H}$ uolena osalla kirjoittajista on, että sosialisaation käsite kolonialisoi koko pedagogisen toiminnan käsitteen ja alistaa kasvatuksen sosialisaation käsitteen osaksi. Selkeimmin tämä teema näkyy Pauli Siljanderin tekemässä johdannossa, Jouni Peltosen artikkelissa
Sosialisaatio ja kasvatus empiirisen tutkimuksen näkökulmasta, A ri K ivelän artikkelissa Pedagoginen toiminnan teoria ja sosialisaatioteoria ja Henry V iheriävaaran artikkelin loppuosassa. H ieman tiivistäen he toteavat: Lähtökohtana on, että kasvatuksen ja sosialisaation samaistaminen ei ole kasvatustutkimuksen ja pedagogisen teorianmuodostuksen kannalta tyydyttävä ratkaisu. Empiirisanalyyttisen tutkimuksen kannalta sosialisaatio ja kasvatuskäsitteet voidaan erottaa toisistaan ja rekonstruktiivisen tutkimuksen kannalta näiden suhde ei ole niin yksinkertainen. Pedagogisen toiminnan käsitteen avulla (johon kuuluvat sivistyksellisyys, itsenäisen toiminnan vaatimus, kulttuurin presentaatio ja kulttuurin representaatio) muotoiltuna pelkkä kasvavan sukupolven sosiaalistaminen vallitsevaan traditioon ei ole pedagogista toimintaa.

Keskeinen kysymys kuuluu: O nko näin? Näiden neljän artikkelin ongelmana on sosialisaatio-käsitteen kapea tarkastelu. O ngelmaksi muodostuu se, miten (tietoisuus)filosofinen argumentaatio soveltuu sosiologisten käsitteiden käsittelyyn. Väistämättä tällaisissa tieteiden välisissä pohdinnoissa on otettava joitakin käsitteitä annettuina. Tarkastelukulmasta nousee esiin kaksi ongelmaa:

1. Miten sosialisaation käsitettä on sosiologisen metodin kautta tarkasteltava?
2. Mihin sosiologisiin selitysmalleihin sosialisaation käsite on liitettävä?

E nsimmäiseen ongelmaan - voidaan vastata Durkheimin (1982) metodisääntöjen pohjalta. Durkheimille sosiologian synnyn historia on sama kuin vapautuminen abstraktista sosiaalifilosofiasta ja sosiaalipsykologiasta. Sosidogan me tooisäännöt - teoksessa yhteiskunnalla on objektiivinen olemus, mutta se ei ole alisteinen tahdolle. Sosiaaliset tosiasiat ovat inmisille ulkoisia. Jokainen yksilö syntyy yhteiskuntaan, joka on omalla tavallaan järjestäytynyt. Yhteiskunta muokkaa hänen arvomaailmaansa. Y ksiIö on vain osa kokonaisuutta, pieni yksikkö laajasta systeemistä. K okonaisuuden ominaisuutta on mahdotonta Durkheimin (1982) mukaan dedusoida yksittäisistä yksilöistä käsin. Sosiaalisissa faktoissa on kysymys ryhmän kollektiivisista uskomuksista, pyrkimyksistä ja tavoista ja nämä ovat eri asioita, kuin yksittäisissä tajunnoissa esiintyvät ajatukset.

Sosiologia on Durkheimin (1982) mukaan tiede sui generis. Sosiaaliset faktat ovat selitettävissä toisten sosiaalisten faktojen termeillä. Selitysmallit voivat sosiologiassa olla kausaalisia tai funktionaalisia. M olemmat täytyy kuitenkin erottaa psykologisesta reduktionismista, joka uhkaa etenkin funktionaalista selittämistä. Funktionaalinen selit- 
täminen edellyttää tosin "pakon" käsitteen, mutta tämä ulkoinen pakko ei ole yksilöön liittyvä (psykologinen), vaan yhteiskuntaan liittyvä (sosiaalinen) ominaisuus. Durkheimin mukaan kollektiiviset uskomukset, tunteet ja tendenssit eivät ole yksilöiden tietoisuuksien seurauksia, vaan sosiaalisten ryhmien seurauksia. Psykologiset tutkimukset ovat sosiaalitieteilijälle hyviä apuvälineitä, mutta ne vain laajentavat sosiologian avulla saatavia tutkimustuloksia. Jokaisen sosiaalisen ilmiön selittäminen psykologian avulla johtaa virheelliseen tulkintaan. Tätä kautta myös mielestäni sosialisaation käsite on ymmärrettävä.

O nko pedagoginen toiminta erotettava sosialisaation käsitteestä? D urkheimiin (1982) viitaten näiden käsitteiden takaa löytyy mahdollisesti eri ilmiöt ja on vain näkökulmakysymys, kummasta yksilö on kiinnostunut (Tornberg 1995). Siljanderin toimittamassa teoksessa nämä näkökulmaerot kiistetään.

\section{Yhteisuntanarali jatkuläpidänän}

T oiseksi artikkelikokoelmassa sivuutetaan pohdinta arvojen, roolin, normin, ryhmän, sosiaalisen paineen, samanlaistumisen ja erilaistumisen sosiaalisen prosessin, vaihdon, solidaarisuuden, jne. merkityksistä yhteiskunnallisen olemisen määrittäjinä. Toivo Salonen tekee aiheeseen tiiviin katsauksen, mutta valitettavasti artikkeli on teoksen viimeisenä ja ei näin "keskustele" alkuosan tekstien kanssa. Tässä valossa tarkastel- tuna kasvatussosiologisten perusmääritelmien (A ntikaisen 1992 ja H irsjärvi \& Huttusen 1991) kritisoiminen saa hieman suhteettoman mittakaavan.

Siljanderin, Peltosen, K ivelän ja Viheriävaaran ansiokkaiden artikkelien ongelmaksi muodostuu sosialisaatio-käsitteen mekaaninen tulkinta. Mikäli kritiikin kohteena on sosiologian selitysmalleista funktionalismi, niin silloin kritiikki osittain osuu maaliinsa. Tätä ei selkeästi teoksessa tuoda esiin. Toinen merkittävä erottelu tehdään yksilön ja yhteiskunnan suhteen. E tenkin Peltosen ja K ivelän artikkeleissa pohditaan näiden kahden position välistä suhdetta. M issään ei kuitenkaan esitetä näkökulmia kolmanteen, sosiologisesti hyvin oleelliseen, tilaan eli organisaatio on (instituution tasoon). Siljander huomauttaa kyllä johdannossaan:

"Taisin ilmaistuna kasvatus on se osa sosialisaatiota, johon osallistuvat eri kasvatusinstituutiot (kasvatus perheessä ja koulutusjärjestemä). Taisaalta vaikuttaa ilmeseltä, etä kasvatuksen ja sosialisaation suhteen määrittämiseksi eivät riitä viitta ukse niihin instituutioihin, jotka modernissa yhteiskunnassa hoitavat sosialisaatiotai kasvatustentävää."

Tämä ei ole vielä aivan tyhjentävä toteamus, jotta arvojen ja vallitsevien yhteiskunnallisten normien tiedostaminen voidaan todeta olevan kasvatusinstituutioille kuulumaton tehtävä. 0 n nimittäin erotettava toisistaan perhemoraali ja yhteiskuntamoraali. N äistä jälkimmäinen (toivottavasti) opitaan koulutus- instituutioissa ja se jatkuu läpi elämän.

$\mathrm{M}$ ielenkiintoiseksi teoksen tekee Asko $\mathrm{K}$ arjalaisen ja Pauli Siljanderin kirjoitus pedagogisen tietoisuuden paradoksista. Perusta artikkelissa on 1920-luvun lopun Erich Wenigerin teorian ja käytännön välisen suhteen kasvatustieteellisessä pohdinnassa. Wenigerin teoreettisessa mallissa yksilön käyttäytymistä ohjaa kolme eri teoriaa. Teoria I kuvaa yksilön sisäistä ja näkymätöntä kasvatuskäytäntöä. Teoria II koskee normatiivisia toimintaohjeita ja teoria III tieteelliseen perusteluun tukeutuvia teorioita. Eri teorioiden suhde toisiinsa aiheuttaa kasvatustilanteissa paradokseja, jotka voivat olla joko ristiriitaisia, antinomisia (eri vastinpareihin liittyviä tai yksityiskohtiin liittyviä) tai arbitraarisia eli satunnaisia. K yse on K arjalaisen ja Siljanderin mielestä siis toiminnan ja reflektion välisestä ristiriidasta.

$\mathrm{K}$ arjalaisen ja Siljanderin esiin nostamaa teemaa on D urkheim (1973) käsitellyt teoksessaan Moral E ducation. Durkheimin (1973) mukaan itse kasvatus ei ole tiedettä, mutta sitä voidaan tutkia tieteen avulla. K asvatuksen on oltava tasavertaista niin maaseudulla kuin kaupungeissakin, ja eri sosiaaliluokissa. Sen avulla Iapsi on sosiaalistettava ympäröivään yhteiskuntaan. K asvatuksesta D urkheim toteaa (D urkheim 1956, 71):

"Education is the influence exerised by adult generations on those that are not yet ready for social life Its dbject is to arouse and to develop in the child a certain 


\section{KBAШSUTTA}

number of physical, intelectual and moral states which are demanded of him by both the political socity as a whole and the special milieu for which he is spedfically destined."

K asvatuksessa on siis eriytettävä toisistaan varhaislapsuuteen liittyvä perhemoraali ja aikuisuuteen liittyvä yhteiskuntamoraali. Jälkimmäinen opitaan nimenomaan koulussa aikuisen opettajan välityksellä. Durkheimille (1973) moraali on itsekuria, jota ohjaa auktoriteetti ja säännöllisyys. Se, miten rajoja on asetettava haluillemme, tulisi opettaa myös lapsille. I hmisen on siis tärkeätä tietää rajojen todellinen luonne ja tätä itsekontrollin kapasiteettia kasvatuksen tulee kehittää. Tässä tulemme Durkheimin (1973) reflektiota koskevaan määritelmään, eli itsetuntemusta ohjaava sisäinen rajoite voi olla vain reflektio eli sisäisten rajoitusten sisäinen ilmaus. K un ihminen oppii käyttäytymään moraalisesti, hän samalla oppii käyttäytymään sääntöjen mukaan ja näin hän on kykenevä toimimaan myös yhteiskunnassa.
Teoksessa olisi ollut paikallaan käsitellä erityisesti didaktiikkaan liittyvää teemaa, joka olisi ollut irti pedagogiikasta.

$T$ eos on ymmärrettävä klassisen saksalaisen sivistysteorian merkityksen pohdintana. Suurin kritiikki siinä kohdistuu anglo-amerikkalaiseen ja ranskalaiseen funktionalistiseen ja pragmaattiseen suuntaukseen. Teoksessa ansiokkaasti valotetaan hyvin erilaisia näkökulmia sosialisaation käsitteeseen. Teokseen sisältyvien artikkelien näkökulmaerot eivät häiritse lukijaa, vaan johdantoluvun jälkeen teosta voi lukea valikoiden.

K eskusteluavaus on tehty ja mielenkiinnolla voidaan jäädä odottamaan, mihin suuntaan saksalainen kasvatustiede kehittyy 1990-Iuvulta alkaen. Vieläkö sivistysteoreettinen suuntaus pitää pintansa saksalaisessa kulttuuripiirissä? A inakin tämän teoksen valossa tarkasteltuna se tulee elämään vahvana 0 ulussa.

Aki Tornberg

\section{Lähteet}

AN TIK AINEN, A. 1992. Kasva tus, koulutus ja yhteiskunta. Porvoo:WSOY.

DURK HEIM , É. 1956. Education and soidogy. $\mathrm{N}$ ew York: The Free Press.

DURKHEIM , É . 1973. Moral education. A study in the theory \& application of the sodiogy of education. $\mathrm{N}$ ew York: The Free Press.

DURKHEIM , É. 1982. Sosidogan metodisäännöt. H elsinki: Tammi.

HIRSJÄRVI, S. \& Huttunen, J. $1991 . J$ Johdatus kasvatus tieteseen. Juva: WSOY.

LAHDES, E. \& Kari J. 1994. Didaktiikka kasvatustieteen osaalueena ja sen keskeiset teoriamallit. Teoksessa J. K ari (to im.) Didaktiikka ja opetussuunnitteu. Porvoo:WSOY. 10-63.

TORNBERG，A， 1995. Reflektiosta refleksioon. Reflektio-käsitteen teoria-historialliset taustat (kasvatus)sosiologian näkökulmasta tarkasteltuna. Julkaisematon sosiologian laudatur-työ. Lapin yliopisto; Y hteiskuntatieteiden tiedekunta. 